\title{
Trade Integration and Business Cycle Synchronization in Latin American Countries
}

\author{
Young Ji Kim ${ }^{1}$ and Sunghyun Kim ${ }^{1+}$ \\ ${ }^{1}$ Sungkyunkwan University, Republic of Korea
}

\begin{abstract}
This paper investigates the relationship between business cycle synchronization and trade integration in the Latin American region. Using data for 17 Latin American countries and the United States (US) from 1980 to 2018, we document the time-series characteristics of business cycle synchronization and intraand inter-regional trade in the region and empirically test whether trade integration contributed to business cycle synchronization. The data demonstrate that the business cycle synchronization index has been steadily increasing in the region. Regional trade integration increased until the financial crisis in 2008 and decreased slightly thereafter. The results of a system generalized method of moments (GMM) regression indicate that bilateral trade with the US significantly increased business cycle synchronization in the region, except during the 2000s, while regional trade had no significant effect. These results emphasize the importance of the indirect trade channel, especially with the US, as a main channel of business cycle synchronization in Latin America.
\end{abstract}

Keywords: Business cycle synchronization, external trade linkages, indirect trade channel, regional integration, Latin America

Received 1 October 2019, Revised 12 July 2020, Accepted 15 August 2020

\section{Introduction}

Rather than following in the footsteps of Europe and forthrightly establishing a monetary union, Latin American countries have instead made an effort to achieve regional economic integration using free trade agreements such as the Southern Common Market (MERCOSUR). How regional trade integration affects the macroeconomic relationship between countries, business cycle synchronization specifically, is quite relevant in determining optimal macroeconomic policy coordination in the region. Trade linkages and international business cycles have implications on the optimal exchange rate regime in the region, whether a country should follow a floating

\footnotetext{
+Corresponding Author: Sunghyun Kim

Professor, Department of Economics, Sungkyunkwan University, 25-2, Sungkyunkwan-ro, Jongno-gu, Seoul, Republic of Korea, Email: shenrykim@skku.edu

Co-Author: Young Ji Kim

Graduate Student, Department of Economics, Sungkyunkwan University, 25-2, Sungkyunkwan-ro, Jongno-gu, Seoul, Republic of Korea, Email: yjik122@gmail.com
} 
or pegged exchange rate system. If countries follow similar business cycles due to more integrated trade, then forming a fixed exchange rate area entails lower costs from the loss of monetary policy independence.

Theoretical predictions on how trade integration influences business cycle synchronization depend on trade characteristics. If greater trade integration prompts more specialization in certain industries (inter-industry trade), this can reduce business cycle correlation. ${ }^{1)}$ However, trade within an industry (intra-industry trade) can amplify business cycle correlation as countries face similar industry-specific shocks. ${ }^{2)}$ Although two countries do not trade directly, if they trade heavily with a common trading partner, then the business cycles of the two countries can become correlated through the main trading partner's business cycles, an indirect trade linkage. Therefore, this indirect trade linkage must be considered to fully understand the relationship between trade integration and business cycle synchronization.

In this paper, we use data for 17 Latin American countries from 1980 to 2018 and document the time-series characteristics of regional business cycle synchronization and trade integration. Then, we test whether trade integration contributes to business cycle synchronization in the region using empirical regressions. Since most literature on the topic of business cycle synchronization and trade integration focuses on the Eurozone and East Asia, this study on the Latin American region contributes to filling a gap in the literature.

Due to the lack of industry-specific trade data for many sample countries, we do not analyze the different roles played by intra- vs. inter-industry trade in this paper. Instead, we focus on indirect trade linkages by examining the role of trade integration within the region and with a common trading partner in impacting business cycle synchronization. We choose the United States (US) as the common trading partner in the analysis because most sample countries report the US as being one of their top trading partners. Table 1 shows that the average regional trade share with the US is approximately $0.29 \sim 0.36$ during various sample periods, exceeding the trade share with the European Union (EU), which is around 0.12 0.22. Furthermore, 11 sample countries have free trade agreements with the US. $\left.{ }^{3}\right)$

1) Literature in this direction started from Eichengreen (1992) and Krugman (1993).

2) See, for example, Frankel and Rose (1998).

3) Eleven countries that have free trade agreements with the US are Chile, Colombia, Costa Rica, Dominican Republic, El Salvador, Guatemala, Honduras, Mexico, Nicaragua, Panama, and Peru. 
Table 1. Trade Share with the US, EU, and Latin American Countries

<1980-1989>

\begin{tabular}{ccccccc}
\hline & US & LA & EU & US & LA & EU \\
\hline ARG & 0.12 & 0.19 & 0.26 & 0.10 & 0.39 & 0.23 \\
BOL & 0.21 & 0.51 & 0.14 & 0.24 & 0.40 & 0.14 \\
BRA & 0.24 & 0.11 & 0.25 & 0.20 & 0.21 & 0.26 \\
CHL & 0.21 & 0.15 & 0.29 & 0.16 & 0.17 & 0.21 \\
COL & 0.32 & 0.09 & 0.33 & 0.40 & 0.16 & 0.21 \\
CRI & 0.39 & 0.23 & 0.25 & 0.38 & 0.17 & 0.21 \\
DOM & 0.66 & 0.01 & 0.12 & 0.53 & 0.01 & 0.11 \\
ECU & 0.52 & 0.14 & 0.06 & 0.21 & 0.46 & 0.17 \\
SLV & 0.39 & 0.24 & 0.25 & 0.18 & 0.33 & 0.21 \\
GTM & 0.33 & 0.31 & 0.21 & 0.50 & 0.11 & 0.11 \\
HND & 0.53 & 0.08 & 0.14 & 0.83 & 0.04 & 0.20 \\
MEX & 0.62 & 0.06 & 0.37 & 0.34 & 0.26 & 0.05 \\
NIC & 0.13 & 0.14 & 0.17 & 0.36 & 0.20 & 0.24 \\
PAN & 0.55 & 0.13 & 0.31 & 0.23 & 0.05 & 0.25 \\
PRY & 0.04 & 0.34 & 0.18 & $\mathbf{0 . 3 2}$ & 0.15 & 0.25 \\
PER & 0.31 & 0.12 & $\mathbf{0 . 1 9}$ & 0.22 & & 0.21 \\
URY & 0.11 & $\mathbf{0 . 3 3}$ & & 0.25 & & 0.17 \\
average & & 0.30 & 0.19 &
\end{tabular}

$<2000-2009>$

$<2010-2018>$

\begin{tabular}{|c|c|c|c|c|c|c|}
\hline & US & LA & EU & US & LA & EU \\
\hline ARG & 0.10 & 0.40 & 0.16 & 0.06 & 0.35 & 0.12 \\
\hline BOL & 0.13 & 0.54 & 0.05 & 0.11 & 0.56 & 0.07 \\
\hline BRA & 0.19 & 0.20 & 0.21 & 0.11 & 0.18 & 0.16 \\
\hline CHL & 0.16 & 0.18 & 0.19 & 0.13 & 0.17 & 0.12 \\
\hline $\mathrm{COL}$ & 0.43 & 0.19 & 0.12 & 0.33 & 0.25 & 0.12 \\
\hline CRI & 0.45 & 0.22 & 0.14 & 0.40 & 0.27 & 0.17 \\
\hline DOM & 0.75 & 0.02 & 0.07 & 0.50 & 0.04 & 0.06 \\
\hline ECU & 0.43 & 0.29 & 0.13 & 0.39 & 0.27 & 0.12 \\
\hline SLV & 0.58 & 0.34 & 0.04 & 0.47 & 0.45 & 0.03 \\
\hline GTM & 0.44 & 0.38 & 0.05 & 0.37 & 0.40 & 0.07 \\
\hline HND & 0.44 & 0.27 & 0.17 & 0.35 & 0.28 & 0.23 \\
\hline MEX & 0.85 & 0.04 & 0.04 & 0.80 & 0.06 & 0.04 \\
\hline NIC & 0.36 & 0.39 & 0.12 & 0.41 & 0.26 & 0.07 \\
\hline PAN & 0.46 & 0.18 & 0.16 & 0.21 & 0.18 & 0.20 \\
\hline PRY & 0.02 & 0.77 & 0.06 & 0.02 & 0.59 & 0.13 \\
\hline PER & 0.25 & 0.17 & 0.14 & 0.16 & 0.16 & 0.14 \\
\hline URY & 0.11 & 0.39 & 0.15 & 0.05 & 0.32 & 0.10 \\
\hline average & 0.36 & 0.29 & 0.12 & 0.29 & 0.28 & 0.12 \\
\hline
\end{tabular}


We first calculate various indices for business cycle synchronization and trade integration following empirical regression methodologies widely used in the literature. Data analysis indicates a steady increase in regional business cycle synchronization, while regional trade integration increased through 2008 and then slightly decreased. The system generalized method of moments (GMM) regression confirms that the regression coefficients for bilateral trade intensity among Latin American countries are insignificant for all regressions, indicating that regional trade does not increase business cycle synchronization. Conversely, the trade intensity index with the US generates a positive and significant effect on business cycle synchronization. Including only direct trade linkages in the regression might generate an inaccurate inference on the role of trade integration in business cycle synchronization and how indirect trade linkages with a main trading partner such as the US contributes to business cycle synchronization. These results suggest that increasing trade with common trading partners can be an alternative strategy for increasing regional business cycle synchronization.

The trade channel is not the only channel through which shocks in one country can be transmitted to another country. Financial linkages through international asset holdings can also contribute to business cycle synchronization. Cross-country stock and bond holdings can transmit shocks across countries through the risk-sharing channel, wealth effects, and balance sheet effects.4) However, Latin American financial markets are not well-developed and cross-country asset holdings among Latin American countries are quite small in size. Moreover, data for cross-country asset holdings are not available for many countries in the region. Therefore, we do not include the financial channel in this analysis.

The rest of the paper is structured as follows. Section II introduces the related literature. Sections III and IV explain the data and descriptive statistics on business cycle synchronization and trade intensity measures. Section V presents the panel regression results and Section VI concludes.

\section{Literature Review}

Studies on trade integration and business cycles date back to Frankel and Rose (1998), who focused on the endogeneity of trade integration and business cycle synchronization as a criterion for establishing an optimum currency area. They argued that the relationship between trade integration and business cycle correlation is theoretically ambiguous because it depends on trade structure. A set of subsequent papers used similar gravity models with instrumental variables and empirically demonstrated the significant effect of trade integration on business cycle

4) See Imbs (2006), Kalemli-Ozcan et al. (2013), and Davis (2014) for a detailed explanation of the financial channel. 
synchronization. However, other papers have reported contradictory results. Inklaar et al. (2008) used a multivariate regression model and showed that the effects of trade integration on the business cycle were weak for the OECD countries.

The importance of intra-industry trade for business cycle synchronization has been widely studied both theoretically and empirically. Imbs (2004) credited intra-industry trade as an important reason underlying the considerable influence of trade integration on business cycle synchronization. Gong and Kim (2013) examined the effect of external and internal trade linkages on business cycle synchronization and discovered that both have a significant effect. Li (2017) used panel regressions with random effects and showed that intra-industry trade had a positive and significant effect on business cycle synchronization in Asia.5) It is widely known that East Asian countries have a vertical intra-industry trade structure among themselves, which may explain why intra-industry trade research is primarily conducted in this region. Another region emphasized in the literature is Europe, primarily the Eurozone. Rana et al. (2012) compared the relationship between business cycle synchronization and intra-industry trade in Europe and Asia. They concluded that the effect of intra-industry trade is stronger and more decisive for East Asia than Europe. Saiki and Kim (2014) used Eurozone and East Asian data and demonstrated that increased intra-industry trade, particularly, vertical intra-industry trade, positively impacted business cycle synchronization.

While most previous papers have focused on developed countries, some have analyzed developing countries. Calderón et al. (2007) investigated whether the relationship between trade integration and business cycle synchronization are different for developing countries. They empirically showed that trade integration had an overall "weaker and ambiguous" impact on business cycle synchronization for developing countries due to specialization, differences in production, and lower trade volumes.

A few articles have analyzed trade integration and business cycle synchronization in the Latin American region. Fiess (2007) analyzed business cycle synchronization in Central America and illustrated a positive relationship between the degree of business cycle synchronization and trade intensity.6) Miles (2017) analyzed the relationship between dollarization and business cycle synchronization with the US. Some articles focused on general economic integration issues in Latin America, such as Márquez-Ramos et al. (2017) and Basnet and Sharma (2013, 2015), who supported the view that business cycles in Latin American countries generally follow a similar pattern over time.

5) Not all papers have provided favorable results on intra-industry trade. Cortinhas (2007) showed a marginally significant relationship between business cycle synchronization and intra-industry trade using Association of Southeast Asian Nations (ASEAN) data.

6) Related articles include Kandil (2011) and Caporale and Girardi (2016). 


\section{Data}

We selected 17 Latin American and Central American countries for the sample: Argentina, Bolivia, Brazil, Chile, Colombia, Costa Rica, Dominican Republic, Ecuador, El Salvador, Guatemala, Honduras, Mexico, Nicaragua, Panama, Paraguay, Peru, and Uruguay.7) We focus on two variables: the business cycle synchronization index and the bilateral trade intensity index.

The most common measure of economic activity used in calculating business cycle synchronization is real GDP. We use real annual GDP data from the IMF World Economic Outlook Database for the sample period of 1980-2018. We derive the business cycle synchronization index, following the work of Kalemli-Ozcan et al. (2013), and named it business cycle synchronization (BCS) Index 1:

$$
\rho_{i, j, t}=-\left|\left(\ln Y_{i, t}-\ln Y_{i, t-1}\right)-\left(\ln Y_{j, t}-\ln Y_{j, t-1}\right)\right|
$$

This index is defined as the negative of divergence, which is the absolute value of the difference between the real GDP growth rates of countries $i$ and $j$. The larger the value (the closer to zero), the higher the degree of synchronization.8)

In addition, we use another BCS index (BCS Index 2) following Morgan et al. (2004). The GDP growth rate of each country is used as the dependent variable and the regression is run on country $\left(\gamma_{i}\right)$ and year $\left(\varphi_{t}\right)$ fixed effects to derive residual $\left(v_{i, t}\right)$, as in (2). The residual represents country $i$ 's "deviation from average growth." Using these residuals, we derive a BCS measure by taking the negative of the absolute value of the difference between the residuals of country $i$ and $j$, as in (3). As in BCS Index 1, the closer the value is to zero, the higher the degree of synchronization.

$$
\begin{aligned}
& \ln Y_{i, t}-\ln Y_{i, t-1}=\gamma_{i}+\varphi_{t}+v_{i, t}, \forall i \\
& \rho_{i, j, t}^{2}=-\left|v_{i, t}-v_{j, t}\right|
\end{aligned}
$$

To quantify the intensity of bilateral trade among the sample countries, we constructed the index following the work of Frankel and Rose (1998):

7) We excluded dependencies and the Caribbean region. Cuba and Venezuela were also removed due to data complications.

8) Various papers have opted for bilateral correlations of "real economic activity," specifically, the cyclical components of real GDP. However, the downside of using these cyclical components is that no consensus on the optimal derivation method exists and filtering techniques tend to be situationally sensitive and are susceptible to self-selection estimation errors. 


$$
T I_{i, j, t}=\frac{X_{i, j, t}+M_{i, j, t}}{X_{i, t}+X_{j, t}+M_{i, t}+M_{j, t}}
$$

This index calculates bilateral trade intensity by dividing country $i$ and $j$ 's bilateral trade volume (export $X_{i, j, t}$ plus import $M_{i, j, t}$ ) by the sum of each country's total trade volume $\left(X_{i, t}+X_{j, t}+M_{i, t}+M_{j, t}\right)$. A larger value indicates greater trade intensity between the two countries. All export and import data were collected from the IMF's Direction of Trade Statistics Database. 9)

Since Latin American countries engage in substantial trade with the US, we investigate trade intensity with the US as a potential explanatory variable for BCS. Country $i$ and $j$ 's trade intensity with the US is measured by the sum of each countries' trade intensity with the US, as follows:

$$
T I_{i, j, U S A, t}=\frac{X_{i, U S A, t}+M_{i, U S A, t}}{X_{i, t}+X_{U S A, t}+M_{i, t}+M_{U S A, t}}+\frac{X_{j, U S A, t}+M_{j, U S A, t}}{X_{j, t}+X_{U S A, t}+M_{j, t}+M_{U S A, t}}
$$

where $X_{i(j), U S A, t}$ denotes the exports of country $i(j)$ to the US and $M_{i(j), U S A, t}$ denotes the imports of country $i(j)$ from the US. The denominator is the sum of all trade between country $i(j)$ and the US. This index represents the indirect trade channel between countries $i$ and $j$ through the US. Even though no direct trade between countries $i$ and $j$ exists, if both countries trade heavily with the US, then this index captures the degree of indirect trade integration.

Since there are two bilateral trade intensity indices between countries $i$ and $j$ (direct and indirect through the US), the index in Equation (4) will be referred to as 'regional bilateral trade intensity' hereafter to prevent any confusion.

\section{Descriptive Statistics}

This section presents the statistical properties of the indices used in the regression-BCS, regional bilateral trade intensity, and bilateral trade intensity with the US - to identify any patterns or trends over time.

9) When collecting bilateral trade data, the standard is for country $i$ to be the reporting country. However, for certain country pairs in certain years, there are no reported trade data. Before treating these as zero trade flows, if there is a reported trade value when country $j$ is the reporting country, then that value is used instead, because theoretically, $X_{i, j, t}$ should be equal to $M_{j, i, t}$. This does not affect the integrity of the index because each country pair is considered only once to avoid double-counting. 


\section{A. Business cycle synchronization index}

First, for each sample country, we calculate BCS Index 1 for each trading partner and take a simple average of these values, which is shown in Figure 1. We can observe that some countries have quite different business cycles from the rest of the region, in particular during the crisis period. In 1982, Chile went through an economic crisis that caused a $14.3 \%$ GDP retraction. This led to a divergence between the Chilean business cycle and that of the region. Peru underwent significant political crisis in 1989, which caused its business cycle to diverge from the rest of Latin America. Mexico in 1995 and Argentina in 2002 are two other examples. Despite the considerable instability experienced in some countries, each country's synchronization level improved over 1980-2018 sample period.

Figure 1. Time-series graph of the business cycle synchronization index

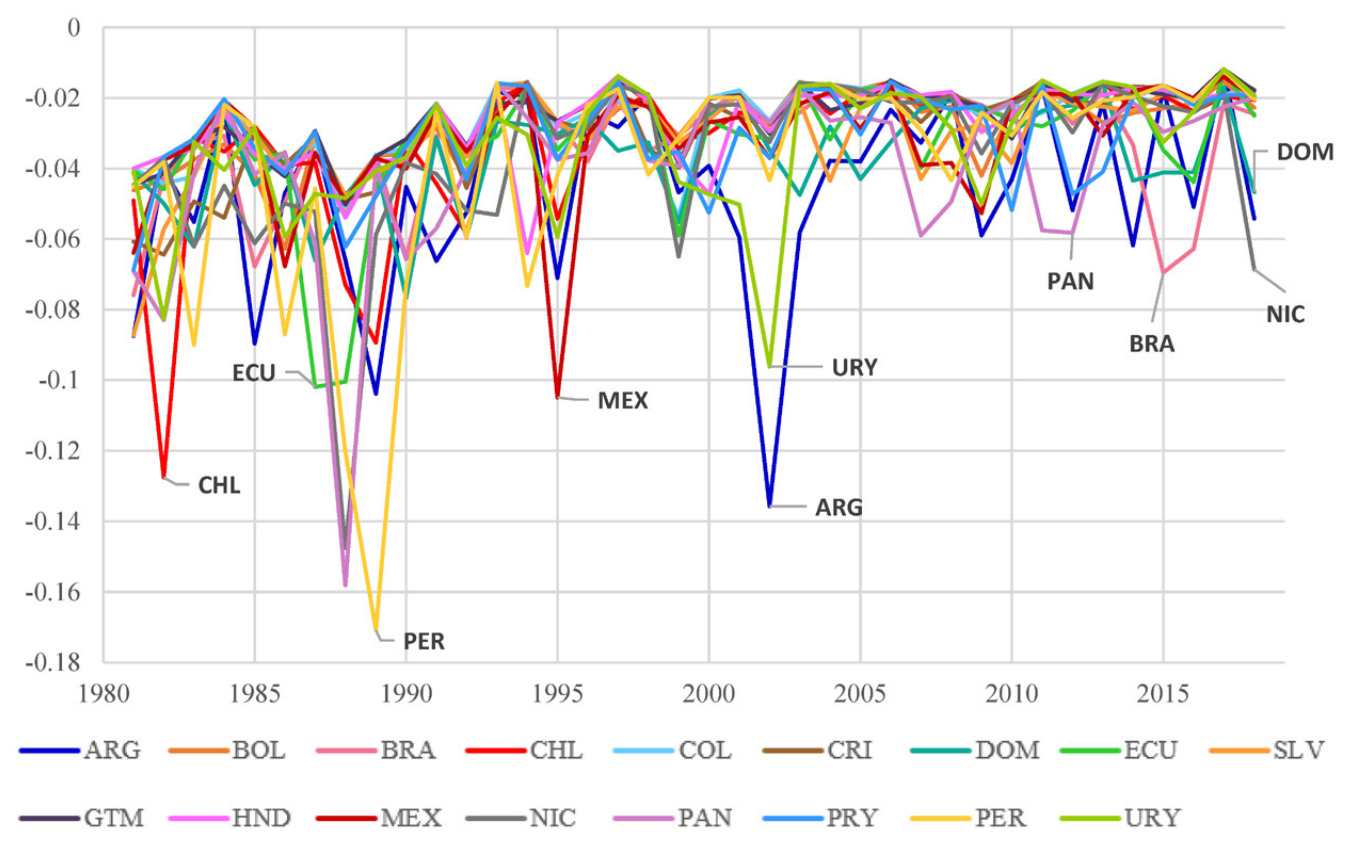

Note. The graph was constructed by taking a simple average of all pairwise indices of each country.

Next, we construct a regional average by averaging all sample countries' indices either by a simple or a weighted average where the weight is size of GDP, as shown in Figure 2. The scale for the simple average is on the left-hand side of the graph while the scale for the weighted average is on the right-hand side. Both the simple and weighted averages show a similar pattern. One interesting feature is that the weighted average is much higher than the simple average, which means that larger economies in the region have more similar business cycles. ${ }^{10)}$ The results with BCS Index 2 are similar to those with BCS Index 1, so they are not reported herein. 
Figure 2. Average of the business cycle synchronization index

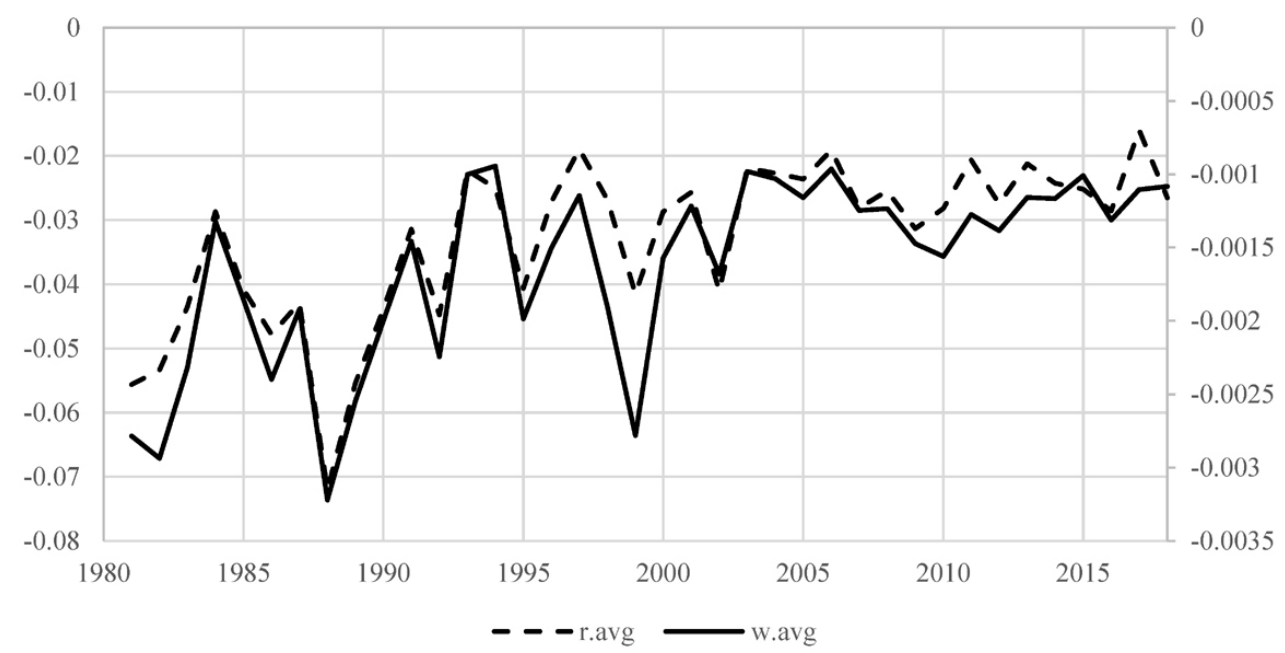

Note. r.avg is a simple average (scaled at the left axis) and w.avg is a weighted average (scaled at the right axis) of all sample countries' indices shown in Figure 1.

Figure 2 illustrates that, over time, the ups and downs of BCS in the Latin American region have increased. It was noticeably more volatile during the 1980 s and 1990 s than the 2000s. Debt crises in the region during 1980s - namely, the Mexican crisis and the subsequent Tequila effect in the mid-1990s - increased this measure's volatility. In the 2000s, apart from a relatively minor decline during the global financial crisis (GFC), this region's BCS has remained quite stable.11) Additionally, the degree of synchronization is quite high as the values stay close to zero, especially in the weighted index. This region's overall increase in BCS over time can be attributed to concurrent political and economic reforms, increased trade and financial liberalization, deregulation, and inflation control.

\section{B. Bilateral trade intensity index}

Figure 3 shows the regional bilateral trade intensity index for each country, which is calculated by adding the pairwise indices together. This captures the entire regional trade amount of each country (as a percentage of total trade). There is a wide range of regional trade intensity among countries. For example, Mexico has a continuously, fairly low share of intra-regional

10) When the weighted average is larger than the simple average, it means that larger countries' BCS indices are higher than those of smaller countries. If larger countries have lower BCS indices than smaller countries, then the weighted average should be lower than the simple average because the larger countries' measures count more in calculating the weighted average.

11) According to Pastor and Wise (2015), the global financial crisis having a marginal effect on Latin American countries is neither an error nor a stroke of luck; rather, it illustrates that the policy reforms and industrial modernization were successful in helping the region build economic resilience. 
trade. Due to the North American Free Trade Agreement, Mexico trades with the US and Canada more than with Latin American countries. Countries with the highest degree of intra-regional bilateral trade are Argentina and Brazil, two of the region's bigger and more globally prominent countries, with their highest values at around 17\%. Apart from these countries, most countries are clustered in the middle, sharing a similar starting point of around $6 \%$ and gradually increasing their shares over time. Despite the increasing trend, the absolute value of regional trade among Latin American countries is fairly low compared to other regions such as Asia.

Figure 3. Time-series graph of regional bilateral trade intensity

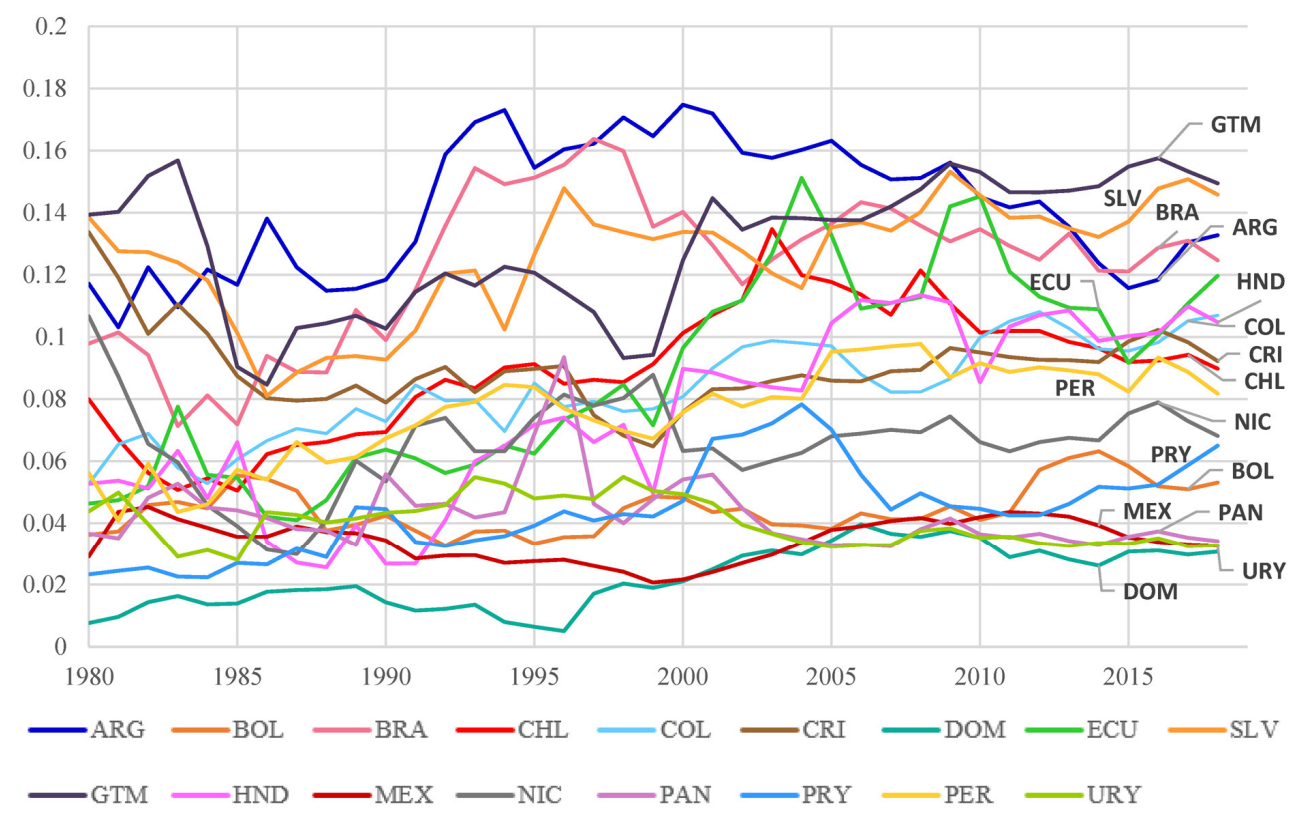

Note. The graph was constructed by summing up all pairwise indices of each country.

Figure 4 shows the simple average of all countries' regional bilateral trade intensity indices. The figure indicates that a significant setback occurred during the 1980s debt crisis wherein the region's trade volume decreased. Since late 1980s, regional trade has sharply increased due to trade liberalization, specifically, since MERCOSUR was formed in 1991. In general, the index increased until the 2008 GFC and then slightly decreased over time. This recent decline could be a reflection of increased globalization, which has led to more trade with countries outside of the region. 
Figure 4. Average of regional bilateral trade intensity

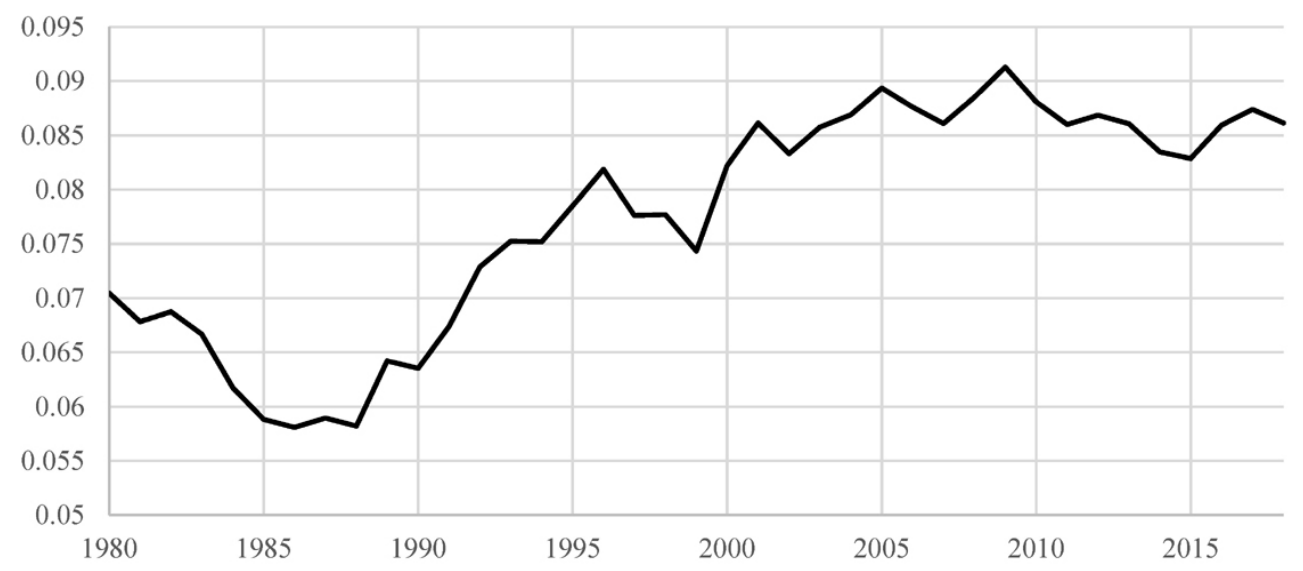

Note. The graph was constructed by taking a simple average of all indices in Figure 3.

Figure 5 illustrates the regional average of bilateral trade intensity with the US, which is calculated by averaging each country's index. The figure shows a consistently increasing trend over time, which means that, on average, Latin American countries have continuously increased trade with the US.12)

Figure 5. Average of bilateral trade intensity with the US

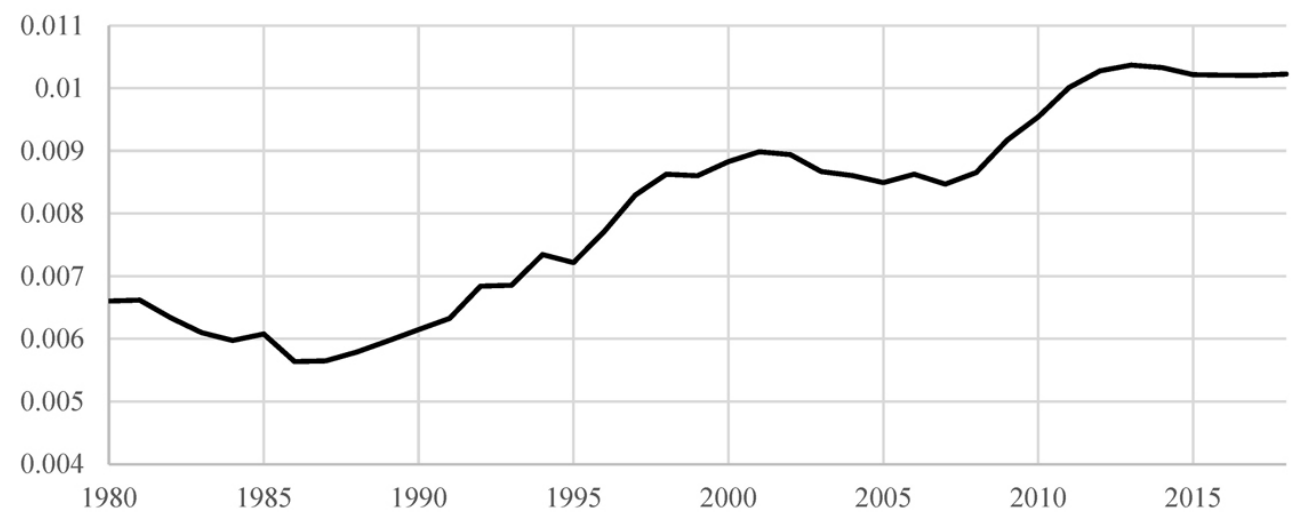

Note. The graph was constructed by taking a simple average of all pairwise indices of each country.

\section{Panel Regression Results}

As in Frankel and Rose (1998), we use the following panel regression model to analyze

12) We do not provide a country-specific graph because the index values are too widely dispersed to put in one graph. 
the relationship between $\mathrm{BCS}$ and the bilateral trade intensity index:

$$
\rho_{i, j, t}=\beta_{0}+\beta_{1} T R A D E_{i, j, t}+\varepsilon_{i, j, t}
$$

where $\rho_{i, j, t}$ denotes the BCS index and $T R A D E_{i, j, t}$ stands for the bilateral trade intensity measure. For the bilateral trade intensity measure, we use regional bilateral trade intensity $\left(T I_{i, j, t}\right)$ or bilateral trade intensity with the US $\left(T I_{i, j, U S A, t}\right)$, and both simultaneously.

For estimation, we use the GMM method, which can deal with issues of endogeneity and heteroscedasticity in dynamic panel data. In particular, we follow the work of Arellano and Bover (1995) and Blundell and Bond (1998) and use system GMM estimation. ${ }^{13)}$ Since BCS can be highly affected by global shocks propagated through the contagion effect, we use a dummy variable to control for the GFC. We use various time periods to observe if the results are consistent in different sample periods.

Table 2 presents the estimation results for the entire 1980-2018 sample period using BCS Index 1 (top panel) and Index 2 (bottom panel). Regression 1 shows the results when only regional bilateral trade intensity is considered as a regressor. Regression 2 shows the results when only bilateral trade intensity with the US is considered as a regressor. Finally, Regression 3 shows the results when both bilateral trade intensity measures were included as regressors. All three regressions are analyzed with and without the crisis dummy.

In all regressions, the coefficients on the regional trade intensity index are positive but not significant, when analyzed separately as well as together with trade intensity with the US. In contrast, trade intensity with the US has a positive and significant coefficient in all regressions with and without the regional trade intensity index. ${ }^{14)}$ This result suggests that regional trade integration among Latin American countries does not explain BCS and the role of trade integration with the US is more important in causing Latin American countries' cycles to converge. Traditional bi-variate analysis between regional trade integration and BCS can lead us to the incorrect conclusion that trade integration has no explanatory power regarding BCS. The role of the indirect trade channel is more important in explaining BCS. Results with BCS Index 2 indicate that all coefficients become slightly lower than those from BCS Index 1 but are quite similar to each other. Therefore, we will only report BCS Index 1 results hereafter. The crisis dummy does not play any role in this regression.

To trace how the effects of trade integration on BCS changed over time, we report sub-period

13) As mentioned in Paramanik (2015), the system GMM has numerous advantages over difference GMM, such as endogeneity control for "dependence among explanatory variables" and unbiased results even when heteroscedasticity is present.

14) We cannot directly compare the size of coefficients for regional trade intensity and trade intensity with the US because the two regressors are measured in different units. Therefore, we focus on the significance of the coefficients in this study. 
Table 2. System GMM Regression Results: Entire Sample Period (1980-2018)

$<$ BCS Index 1>

\begin{tabular}{lcccccc}
\hline & \multicolumn{2}{c}{ Reg. 1 } & \multicolumn{2}{c}{ Reg. 2} & \multicolumn{2}{c}{ Reg. 3 } \\
\hline \multirow{2}{*}{ Constant } & $-0.030^{* * *}$ & $-0.030^{* * *}$ & $-0.036^{* * *}$ & $-0.036^{* * *}$ & $-0.038^{* * *}$ & $-0.038^{* * *}$ \\
& $(0.0018)$ & $(0.0017)$ & $(0.0023)$ & $(0.0018)$ & $(0.0017)$ & $(0.0023)$ \\
\hline \multirow{2}{*}{$\mathrm{TI}_{\mathrm{i}, \mathrm{j}, \mathrm{t}}$} & 0.458 & 0.460 & & & 0.434 & 0.437 \\
& $(0.31)$ & $(0.31)$ & & & $(0.309)$ & $(0.310)$ \\
\hline \multirow{2}{*}{$\mathrm{TI}_{\mathrm{i}, \mathrm{j}, \text { usa,t }}$} & & & $0.529^{* * *}$ & $0.529^{* * *}$ & $0.529^{* *}$ & $0.529^{* * *}$ \\
\hline \multirow{2}{*}{ Financial Crisis Dummy } & & $(0.09)$ & $(0.09)$ & $(0.08)$ & $(0.08)$ \\
& & -0.0005 & & -0.0007 & & -0.0007 \\
& & $(0.0015)$ & & $(0.0015)$ & $(0.0015)$ \\
\hline
\end{tabular}

$<$ BCS Index 2>

\begin{tabular}{lcccccc}
\hline & \multicolumn{2}{c}{ Reg. 1 } & \multicolumn{2}{c}{ Reg. 2} & \multicolumn{2}{c}{ Reg. 3 } \\
\hline \multirow{2}{*}{ Constant } & $-0.043^{* * *}$ & $-0.043^{* * *}$ & $-0.049^{* * *}$ & $-0.050^{* * *}$ & $-0.050^{* * *}$ & $-0.050^{* * *}$ \\
& $(0.005)$ & $(0.006)$ & $(0.003)$ & $(0.003)$ & $(0.006)$ & $(0.006)$ \\
\hline \multirow{2}{*}{$\mathrm{TI}_{\mathrm{i}, \mathrm{j}, \mathrm{t}}$} & 0.291 & 0.264 & & & $0.193(1.03)$ & 0.167 \\
\hline \multirow{2}{*}{$\mathrm{TI}_{\mathrm{i}, \mathrm{j}, \mathrm{s}, \mathrm{t}, \mathrm{t}}$} & $(1.02)$ & $(1.03)$ & & & $0.481^{* * *}$ & $0.474^{* * *}$ \\
\hline \multirow{2}{*}{ Financial Crisis Dummy } & & & $0.484^{* * *}$ & $0.476^{* * *}$ & $(0.164)$ & $(0.162)$ \\
\hline
\end{tabular}

Note. ${ }^{* *}, * *$, and $*$ indicate significance at the $1 \%, 5 \%$, and $10 \%$ levels, respectively. Reg. 1 is with the regional bilateral trade intensity index only, Reg. 2 is with the bilateral trade intensity index with the US only, and Reg. 3 is with both indices.

analysis results in Table 3. Since the crisis dummy does not alter the results very much, we report the results without the crisis dummy in this table. We divide the sample period into four sub-periods: 1981-1990, 1991-2000, 2001-2010, and 2011-2018. As indicated in Table 2 , the regional trade integration index is not significant and even demonstrates a negative impact during the 2001-2010 sub-period. The size of the coefficient is largest in the 1980s and decreases over time, suggesting that, over time, regional trade integration became a less important channel for BCS in Latin America. The minimal significance of regional bilateral trade intensity is aligned with the results from Fiess (2007), who also reported a weak relationship between regional trade and BCS. Other structural components that contribute to production and trade networks could result in a weaker relationship between regional bilateral trade intensity and regional BCS, as discussed by Calderón et al. (2007).

However, the coefficient for the trade intensity index with the US is positive and significant in all sub-periods, except for 2001-2010 when the coefficient was significantly negative. A negative coefficient indicates that a higher trade intensity with the US increases the divergence of business cycles in the region. This sub-period includes the GFC period, during which most sample countries suffered through an economic downturn and slowdown in trade, including 
Table 3. System GMM Regression Results: Sub-Period Analysis

$<1981-1990>$

\begin{tabular}{cccc}
\hline & Reg. 1 & Reg. 2 & Reg. 3 \\
\hline \multirow{2}{*}{ Constant } & $-0.046^{* * *}$ & $-0.069^{* * *}$ & $-0.073^{* * *}$ \\
& $(0.004)$ & $(0.007)$ & $(0.009)$ \\
\hline \multirow{2}{*}{$\mathrm{TI}_{\mathrm{i}, \mathrm{j}, \mathrm{t}}$} & 1.084 & & 1.104 \\
& $(0.949)$ & & $(1.026)$ \\
\hline \multirow{2}{*}{$\mathrm{TI}_{\mathrm{i}, \mathrm{j}, \text { usa,t }}$} & & $2.487^{* * *}$ & $2.489^{* * *}$ \\
\end{tabular}

$<1991-2000>$

\begin{tabular}{cccc}
\hline & Reg. 1 & Reg. 2 & Reg. 3 \\
\hline \multirow{2}{*}{ Constant } & $-0.033^{* * *}$ & $-0.035^{* * *}$ & $-0.037^{* * *}$ \\
& $(0.003)$ & $(0.002)$ & $(0.003)$ \\
\hline \multirow{2}{*}{$\mathrm{TI}_{\mathrm{i}, \mathrm{j}, \mathrm{t}}$} & 0.611 & & 0.485 \\
& $(0.422)$ & & $(0.431)$ \\
\hline \multirow{2}{*}{$\mathrm{TI}_{\mathrm{i}, \mathrm{j}, \text { usa, }}$} & & $0.310^{* * *}$ & $0.305^{* * *}$ \\
\end{tabular}

$<2001-2010>$

\begin{tabular}{cccc}
\hline & Reg. 1 & Reg. 2 & Reg. 3 \\
\hline \multirow{2}{*}{ Constant } & $-0.023^{* * *}$ & $-0.015^{* * *}$ & $-0.015^{* * *}$ \\
& $(0.002)$ & $(0.003)$ & $(0.004)$ \\
\hline \multirow{2}{*}{$\mathrm{TI}_{\mathrm{i}, \mathrm{j}, \mathrm{t}}$} & -0.222 & & -0.006 \\
& $(0.397)$ & $-0.387^{* *}$ & $(0.445)$ \\
\hline \multirow{2}{*}{$\mathrm{TI}_{\mathrm{i}, \mathrm{j}, \text { usa,t }}$} & & $(0.188)$ & $-0.388^{* *}$ \\
\hline
\end{tabular}

$<2011-2018>$

\begin{tabular}{cccc}
\hline & Reg. 1 & Reg. 2 & Reg. 3 \\
\hline \multirow{2}{*}{ Constant } & $-0.022^{* * *}$ & -0.056 & $-0.061^{* * *}$ \\
& $(0.003)$ & $(0.014)$ & $(0.016)$ \\
\hline \multirow{2}{*}{$\mathrm{TI}_{\mathrm{i}, \mathrm{j}, \mathrm{t}}$} & -0.071 & & 0.745 \\
& $(0.423)$ & & $(0.614)$ \\
\hline \multirow{2}{*}{$\mathrm{TI}_{\mathrm{i}, \mathrm{j}, \text { usa,t }}$} & & $1.685^{* *}$ & $1.742^{* *}$ \\
\hline
\end{tabular}

Note. ${ }^{* *}, * *$, and $*$ indicate significance at the $1 \%, 5 \%$, and $10 \%$ levels, respectively.

trade with the US. During the 2011-2018 sub-period, however, the coefficient again became positive and significant. Overall, trade integration with the US is a more important factor in driving convergent business cycles in the Latin American region.

Finally, we replicate the regression in Table 2 using a subset of sample countries. Table 4 reports the regression results, excluding Central American countries, so the sample countries include Argentina, Bolivia, Brazil, Chile, Colombia, Ecuador, Paraguay, Peru, and Uruguay. 
The table indicates that the regression results are quite similar to those in Table 2 in that the coefficient on the regional trade intensity index is not significant and the coefficient on trade intensity with the US is significant and positive in all regressions.

Table 4. System GMM Regression Results, Excluding Central American Countries

$<1980-2018>$

\begin{tabular}{lcccccc}
\hline & \multicolumn{2}{c}{ Reg. 1} & \multicolumn{2}{c}{ Reg. 2} & \multicolumn{2}{c}{ Reg. 3} \\
\hline \multirow{2}{*}{ Constant } & $-0.032^{* * *}$ & $-0.032^{* * *}$ & $-0.04^{* * *}$ & $-0.041^{* * *}$ & $-0.041^{* * *}$ & $-0.042^{* * *}$ \\
& $(0.004)$ & $(0.004)$ & $(0.007)$ & $(0.007)$ & $(0.006)$ & $(0.006)$ \\
\hline \multirow{2}{*}{$\mathrm{TI}_{\mathrm{i}, \mathrm{j}, \mathrm{t}}$} & 0.422 & 0.426 & & & 0.233 & 0.239 \\
\hline \multirow{2}{*}{$\mathrm{TI}_{\mathrm{i}, \mathrm{j}, \text { usa,t }}$} & $(0.394)$ & $(0.394)$ & & & $(0.439)$ & $(0.438)$ \\
\hline \multirow{2}{*}{ Financial Crisis Dummy } & & & $1.458^{* *}$ & $1.457^{* *}$ & $1.351^{*}$ & $1.348^{*}$ \\
& & & $(0.665)$ & $(0.669)$ & $(0.726)$ & $(0.730)$ \\
\hline
\end{tabular}

Note. ${ }^{* *}, * *$, and $*$ indicate significance at the $1 \%, 5 \%$, and $10 \%$ levels, respectively. Sample countries include Argentina, Bolivia, Brazil, Chile, Colombia, Ecuador, Paraguay, Peru, and Uruguay.

\section{Conclusions}

Trade linkage has been considered a main factor driving business cycles and numerous previous studies have examined this topic. We make two contributions to the literature. While most studies regarding the relationship between BCS and the trade channel have focused on Europe and Asia, we perform a thorough analysis of the Latin American region in which economic integration and cooperation have been key discussion issues in recent years. Second, while most studies have focused on a role of different types of trade - intra-industry vs. inter-industry trade - on BCS, we investigate the role of the indirect trade channel in generating business cycle correlation through a common trading partner. Even though two countries do not engage in direct trade with each other, trading with a common trade partner can transmit business cycles from one country to another. We cannot simply rule out the role of trade integration on BCS by only analyzing bilateral trade intensity. Indirect trade linkages through a common trading partner such as the US can enhance the role of trade in BCS.

Panel regression results confirm that the role of trade with the US significantly affected BCS in the Latin American region, except during the 2000-2010 period, which includes the GFC. Regional trade integration among Latin American countries has not been a significant factor in driving regional BCS. These results illustrate that even though a number of Latin American countries have engaged in promoting regional trade with various treaties and agreements such as MERCORSUR, the role of regional trade integration has not been effective 
in generating similar business cycles in the region. Rather, trade integration with the US has been the key factor in driving BCS in Latin America.

While regional trade integration should be a primary tool for improving regional macroeconomic coordination, policymakers might be able to find an alternative source for trade integration through other main trading partners such as the EU or China, which would have a significant effect in synchronizing regional business cycles. This analysis also provides some implications regarding the current trend of de-globalization, such as the trade war between the US and China and Brexit, and how they might affect BCS. Lower trade volume and the breakup of vertical trade integration would negatively affect BCS but the analysis of only the direct trade channel might overestimate the cost of de-globalization because trade can exist through common trade partners and be measured by the indirect trade channel.

This study can be extended to include other important trading partners such as the EU and China to measure the indirect trade channel. Another potential way to expand this analysis is by including the financial channel as a medium of business cycle transmission. One limitation is the region's underdeveloped international financial markets and lack of data on cross-country asset holdings. However, the indirect financial channel through the main financial centers might play a role in generating BCS in the Latin American region.

\section{References}

Arellano, M., \& Bover, O. (1995). Another Look at the Instrumental Variable Estimation of Error-Components Models. Journal of Econometrics, 68(1), 29-51.

Basnet, H. C., \& Sharma, S. C. (2013). Economic Integration in Latin America. Journal of Economic Integration, 28(4), 551-579.

Basnet, H. C., \& Sharma, S. C. (2015). Exchange Rate Movements and Policy Coordination in Latin America. Journal of Economics and Finance, 39(4), 679-696.

Blundell, R., \& Bond, S. (1998). Initial Conditions and Moment Restrictions in Dynamic Panel Data Models, Journal of Econometrics, 87(1), 115-143.

Calderón, C., Chong, A., \& Stein, E. (2007). Trade Intensity and Business Cycle Synchronization: Are Developing Countries Any Different? Journal of International Economics, 71(1), 2-21.

Caporale, G., \& Girardi. A. (2016). Business Cycles, International Trade and Capital Flows: Evidence from Latin America. Empirical Economics, 50, 231-252.

Cortinhas, C. (2007). Intra-industry Trade and Business Cycles in ASEAN. Applied Economics, 39(7), 893-902.

Davis, S. (2014). Financial Integration and International Business Cycle Co-movement. Journal of Monetary Economics, 64, 99-111.

Eichengreen, B. (1992). Should the Maastricht Treaty Be Saved? Princeton Studies in International Finance 
No. 74, International Finance Section, Princeton University.

Fiess, N. (2007). Business Cycle Synchronization and Regional Integration: A Case Study for Central America. The World Bank Economic Review, 21(1), 49-72.

Frankel, J. A., \& Rose, A. K. (1998). The Endogeneity of the Optimum Currency Area Criteria. The Economic Journal, 108(449), 1009-1025.

Gong, C., \& Kim, S. (2013). Economic Integration and Business Cycle Synchronization in Asia. Asian Economic Papers, 12(1), 76-99.

Imbs, J. (2004). Trade, Finance, Specialization and Synchronization. The Review of Economics and Statistics, 86(3), 723-734.

Imbs, J. (2006). The Real Effects of Financial Integration. Journal of International Economics, 68, 296-324.

Inklaar, R., Jong-A-Pin, R., \& De Haan, J. (2008). Trade and Business Cycle Synchronization in OECD Countries-A Re-examination. European Economic Review, 52(4), 646-666.

Kalemli-Ozcan, S., Papaioannou, E., \& Peydró, J. (2013). Financial Regulation, Financial Globalization and the Synchronization of Economic Activity. The Journal of Finance, 68(3), 1179-1228.

Kandil, M. (2011). Trade Flows, Financial Linkage, and Business Cycles in Latin America. Journal of Economic Integration, 26, 526-553.

Krugman, P. (1993). Lessons of Massachusetts for EMU. In T. Francisco \& F. Givavazzi (Eds.), Adjustment and Growth in the European Monetary Union (pp. 241-266). Cambridge University Press.

Li, L. (2017). The Impact of Intra-industry Trade on Business Cycle Synchronization in East Asia. China Economic Review, 45, 143-154.

Márquez-Ramos, L., Florensa, L. M., \& Recalde, M. L. (2017). Understanding the Determinants of Economic Integration in Latin America. Journal of Economic Integration, 32, 558-585.

Miles, W. (2017). The Impact of the US on Latin American Business Cycles: A New Approach. Economic Systems, 41, 320-331.

Morgan, D. P., Rime, B., \& Strahan, P. E. (2004). Bank Integration and State Business Cycles. Quarterly Journal of Economics, 119(4), 1555-1584.

Paramanik, R. N. (2015). Analysis of Business Cycle Synchronicity Between India and ASEAN Economies. In K. Majumdar \& P. K. Jena (Eds.) Research Issues in Applied Economics (pp. 199-211). McGraw Hill Education.

Pastor, M., \& Wise, C. (2015). Good-Bye Financial Crash, Hello Financial Eclecticism: Latin American Responses to the 2008-09 Global Financial Crisis. Journal of International Money and Finance, 52, 200-217.

Rana, P. B., Cheng, T., \& Chia, W. (2012). Trade Intensity and Business Cycle Synchronization: East Asia versus Europe. Journal of Asian Economics, 23, 701-706.

Saiki, A., \& Kim, S. H. (2014). Business Cycle Synchronization and Vertical Trade Integration: A Case Study of the Eurozone and East Asia (Working Paper, No. 407). De Nederlandsche Bank. 